\title{
A Component Analysis of "Ideological and Political Competence" in College English Education in China*
}

\author{
Hui Liu \\ School of English, Beijing International Studies University, Beijing, China \\ Satoshi Tsukamoto \\ Department of International Communication, Aichi University, Nagoya, Japan
}

\begin{abstract}
College English course is an effective channel of ideological and political education for students in China. College English can influence students' value orientation and moral standards in an implicit way, and help to improve their comprehensive quality and achieve all-round development. This study interprets "ideology and politics" from the angle of students as a way of thinking, i.e. to be able to think critically, to analyze and evaluate on the basis of knowing and understanding, and to solve real-life problems, so as to successfully internalize knowledge into awareness and ability. Then, the concept "ideological and political competence" is introduced, the component elements are analyzed, the sub-competencies are defined, and a three-pronged model for the cultivation of ideological and political competence in College English is designed.
\end{abstract}

Index Terms-College English, ideological and political education, ideological and political competence, threepronged cultivation model

\section{INTRODUCTION}

Only when a country or a nation has established a common ideal and belief, can it have a strong cohesion and centripetal force, and education plays a vital role. In China, the ultimate goal of education is to foster a new generation of young people capable of shouldering the mission of national rejuvenation, and those who have all-round moral, intellectual, physical, and aesthetical grounding with a hard-working spirit. Within this context, colleges and universities are required to follow the socialist value system to guide students' growth, not only to enhance students' recognition of the core socialist values, but also to cultivate students' ability to put the core socialist values into practice. Ideological and political education is a new concept, which is key to the CPC's overall leadership over colleges and universities, and the implementation of the "three-pronged education". General Secretary Xi Jinping pointed out that we should fully utilize classroom teaching, and while improving ideological and political theory courses, all other courses should play their roles and shoulder responsibilities, so that all courses could work together to produce a synergistic effect.

College English, as a basic course in higher education in China, is regarded as one of the important arenas of ideological and political education for its teaching duration, long class hours, and wide influence. It not only aims to increase students' language knowledge and skills, but also shoulders the mission of transmitting culture, values and virtues. It is a typical course with the dual attributes of "instrumentality" and "humanity". Therefore, College English is both an organic carrier of and an effective channel for ideological and political education for students. It can influence students' value orientation and moral standards in an implicit way, and help to improve their comprehensive quality and achieve all-round development.

\section{IdeOlogical \& Political EduCATion AND COLLEGE ENGLiSH}

The essence of "curriculum ideology and politics" (courses with ideological and political elements) is to integrate the ideological and political education into all aspects of curriculum and teaching. It not only focuses on learning of knowledge while promoting core values, but also emphasizes the transmission of values in the learning process, and thus highlights the integration of explicit teaching and implicit education, so as to realize the goal of moral education (Zong, 2017). Since the $18^{\text {th }}$ National Congress of the CPCC first proposed that the moral education should be the most fundamental task of education, General Secretary Xi has been stressing the significance of ideological and political work in the development of higher education in a series of meetings, including the National Education Conference, the National University Ideological and Political Work Conference and the National Ideological Propaganda Work Meeting.

\footnotetext{
* This research was supported by the fund of the "Demonstration Course of Ideological \& Political Education" project of Beijing International Studies University" ([2021], No. 11111173 )
} 
Teaching innovations and reforms are booming in "Ideological and Political Curriculum" (ideological and political theory courses) and "Curriculum Ideology and Politics". Researchers and teachers have actively carried out relevant research to explore the laws and methods of ideological and political education.

The research on ideological and political issues in the field of College English education has been around for more than 10 years, showing a rapid growth after 2018. First of all, researchers generally believe that it is necessary and important to carry out ideological and political education in College English teaching. College English and ideological and political education have a high degree of consistency in nature, function and content (Liu \& Yue, 2020; Xia \& He, 2019). However, there is in College English teaching a lack of moral education, inadequate coverage of Chinese culture, and ambiguous attitude toward ideological issues. Second, most research focuses on how to integrate the ideological and political content into College English classroom, that is, the strategies, paths and methods of ideological and political teaching in College English course. The research clarifies how to combine College English and ideological and political teaching, and suggests that ideology and politics should be taken as the guideline in goal setting, teaching material construction, teacher training, teaching methods, student evaluation, etc. Elements of ideological and political education should integrate and infiltrate into the whole teaching process so as to form an overall framework of College English ideological and Political Education (Du \& Sun, 2019; Li, 2018). Thirdly, some research focuses on the details, and shows the specific routes and methods of implementing ideological and political education in College English course by means of teaching plans and examples, from topic introduction to discussion, from language knowledge to cultural phenomenon, from critical thinking to evaluation and feedback, from classroom to virtual learning, and so on (Song \& Ma, 2020; Gao \& Xia, 2020). In addition, a small number of studies, from the theoretical perspective, have introduced some relevant theories of pedagogy, psychology, philosophy and other fields into the research of College English ideological and political teaching, such as Bloom-Anderson Taxonomy, Babansky's optimization theory and Wen Qiufang's production-oriented approach. These studies attempt to secure theoretical support for the design of teaching materials and teaching practice (Chen, 2019; Wu, 2020).

In all, the previous studies have clarified the goal and function of ideological and political education in English teaching, and constructed a relatively complete system and feasible implementation path and methods. However, theoretical innovation is insufficient, and empirical studies are even more rarely seen, which makes it difficult for people to see its real nature. This study interprets the concept of "ideological and political" from the perspective of students, and regards it as a way of thinking, that is, to think critically, to analyze and evaluate based on the knowledge learned, so as to successfully internalize ideological and political knowledge into awareness and ability. Then, on this basis, the concept of "ideological and political competence" is introduced, the component elements are analyzed, the sub-competencies are defined, and a three-pronged model for the cultivation of ideological and political competence in College English is designed.

\section{Component AnAlysis of IDEOlogical DNA Political COMPETEnCE}

Feng Qi, a modern Chinese philosopher, once proposed the idea of "transforming theory into method, transforming theory into virtue". It is the process of turning external theory into internal virtue through learning and practice. Similarly, the goal of "curriculum ideology and politics" is to guide students to transform their knowledge into virtues, into inner spirit, and into their own quality or ability, which would help students to understand and change the world (Qiu, 2017). And the transformation or internalization takes place in the cycle of knowing, thinking, doing and hypothesis testing.

"Competence" in Marriam-Webster Dictionary is defined as the quality or state of having sufficient knowledge, judgment, skill, or strength. It is a comprehensive quality showed in an individual for a particular duty or in a particular aspect. The objective of ideological and political education in College English is to cultivate students' competence in the way of thinking and doing within the "socialist core value system". This ideological and political competence is composed of four elements: cognitive competence, thinking competence, practical competence and emotional competence. Ideological and political knowledge in College English involves both language and culture. Language knowledge includes vocabulary, grammar, functions and topics, while cultural knowledge refers to the knowledge about the world, the west and China. Thinking competence is the ability to apply some critical theories to analyze and evaluate political, economic, social, cultural, religious and other issues, so as to form and develop a critical and creative thinking mode. Practical competence refers to students' ability to use ideological and political knowledge to deal with real-life problems in society and intercultural communication, such as "telling Chinese stories and spreading Chinese culture". Finally, emotional competence is the attitude and motivation of students towards the socialist political system and ideological and moral education. Through College English course, students can accept and identify with ideological and political education emotionally, have enough motivation to learn and apply ideological and political knowledge, develop ideological and political thinking, and fulfill ideological and political missions.

\section{A. Cognitive Competence}

First of all, ideological and political knowledge is a series of knowledge about ideology, politics, morality and value, and the sum of descriptions and expressions of relevant facts and information. The cognitive competence is the ability to acquire and master the knowledge. As the ideological and political knowledge covers a wide range of content, we 
must accurately locate its scope within the context of College English, and achieve an organic combination. As Zhao (2019) pointed out, the integration of courses of ideological and political theory and courses with ideological and political elements doesn't mean that they are the same, and the position of each cannot be mixed or misplaced. Ideological and political theory course is the main channel of ideological and political education, while specialized courses and general courses are mainly for intellectual, physical and aesthetic education. As a general course, College English cannot replace or copy the teaching content of ideological and political theory course, so we should grasp the "degree"; the realization of its ideological and political function should be based on the characteristics of the course itself, conform to the laws of language teaching and learning, and transmit value in the way of "infiltration". Also, ideological and political content cannot be separated and disjointed from the course itself.

According to the description of the course nature in the "Guidelines for College English Teaching 2020", College English is both instrumental and humanistic in nature. Instrumentality is mainly reflected in improving the ability of listening, speaking, reading, writing and translating and acquiring the ability of international exchange in academic or professional fields. Humanity shows itself in two aspects: one is to carry out cross-cultural education, that is, to help students better understand foreign countries and cultures, and to strengthen their understanding of the differences; the second is to cultivate students' ability to understand and interpret Chinese culture from new perspectives and to promote it across the world. In view of the integration of ideological and political education and English curriculum and the inseparability of language and culture, the knowledge content of ideological and political education in College English should be mainly about Chinese traditional culture, western language and culture and humanities, and the like. When selecting teaching content or mining the teaching materials available, we should pay special attention to the vocabulary, expressions, discourses and texts loaded with culture and value, and let students learn and understand relevant knowledge through skills training, so as to form a relatively complete knowledge system.

\section{B. Thinking Competence}

Secondly, ideology is a way or manner of thinking characteristic of a group or society. Mode of thinking is closely related to language and culture. Language promotes the formation and development of thinking, while culture influences and restricts thinking. The way of thinking of Chinese college students is bound to be fundamentally influenced by Chinese modern ideologies and politics, traditional culture and moral norms; at the same time, College English, as a language and culture course, also has some penetrating impact on students. Under the cross effect of two different languages and cultures, students should be taught to correctly treat the differences between China and the West, which is closely related to students' thinking competence. The key to the cultivation of thinking competence lies in the training of critical thinking skills. Historical and dialectical materialism, a main part of Marxism, interprets the world and social problems from the perspective of development and connection, and tries to find the laws of historical change. This is consistent with the characteristics of ideal critical thinkers, "inquisitive, trustful of reason, fair-minded in evaluation, prudent in making judgments, ... and persistent in seeking results" (Delphi project, 1990) . In other words, the improvement of critical thinking ability can help students better understand and master historical materialist dialectics, and vice versa.

Moreover, "the Outline of National Medium and Long term Education Reform and Development Plan (2010-2020)" points out that the long-term development of education needs to "promote students' all-round development, strive to improve students' learning ability, practical ability and innovative ability", "stimulate students' curiosity, cultivate students' interests, and create a good environment for independent thinking, free exploration and innovation". It shows that the cultivation of critical thinking ability is one of the ultimate goals of education in China. Bloom-Anderson Taxonomy classifies cognition into six levels, namely, remembering, understanding, applying, analyzing, evaluating and creating. Analyzing, evaluating and creating are the core content and key skills of critical thinking. In College English teaching, teachers should not confine themselves to one teaching method; instead they can employ different approaches, methods and techniques in different teaching contexts. For example, they can assign tasks before class, pay attention to the quantity and quality of "input" during class, stimulate students' discussion and thinking, encourage students' in-depth involvement, and guide them to carry out inquiry-based and research-based learning, so that students can grow into active learners and creative thinkers, and form good habits of thinking while learning.

\section{Practical Competence}

Thirdly, ideological and political education is to enable students to deal with and solve various problems in learning, working, social life, intercultural communication and other situations, so as to serve the needs of the country and society. Students are supposed to form a behavior pattern guided by the core socialist values, to have a good international vision, patriotism, and cross-cultural communication ability, to participate in international affairs, and to spread and transmit Chinese culture. Language is produced in the form of speaking and writing, and ideological and political knowledge needs to be delivered through English as a medium. The application and practice of knowledge and theory will serve as a bridge between the two languages and cultures.

The practical competence is mainly demonstrated in two aspects, namely, intercultural communication and "telling Chinese stories and spreading Chinese culture". Intercultural communication refers to the communication between people speaking different languages or from different cultural backgrounds. Intercultural communication competence needs to be incorporated in the language curriculum and it consists of four elements: global awareness, cultural 
adaptation ability, self- and other knowledge (communicative culture) and practical ability (Yang \& Zhuang, 2007). A successful intercultural communicator needs to be proficient in the target language, be familiar with the target culture and communication rules, and be able to fulfill communicative tasks and resolve disputes. Meanwhile, General Secretary Xi's idea of "telling Chinese stories" is in essence an intercultural communication issue yet with the focus on "self'. It is of great significance to cultivate confidence in Chinese traditional culture and achieve cultural prosperity. It is indispensable for the improvement of the national soft power and building a socialist cultural power in the $21^{\text {st }}$ Century. "Telling a good Chinese story" makes it possible to let the world know about China, change the stereotypes, and improve China's international image. College English ideological and political education should be committed to fostering students' confidence in the nation and the culture. During the training of basic language skills, students should master the means and strategies of storytelling, so that they are able to use understandable and acceptable language and manners to introduce China's history and culture, development path, and institutional innovations to the world.

\section{Emotional Competence}

Emotional competence means that the students are able to identify with core socialist values, have a positive attitude toward the teaching content and methods of ideological and political education in College English, and have a strong willingness to practice the core socialist values and traditional Chinese moral norms. Emotion is very important for cognition, behaviors, and social activities. Emotional competence helps people adapt to the environment, meet challenges and achieve goals. In terms of ideological and political education in College English, it specifically refers to the ability of students to adapt to the teaching, participate in activities, and adjust and regulate their emotions. The first is students' recognition and approval of the ideological and political knowledge content in the course, such as whether they really agree with the core socialist values, whether they are full of confidence in Chinese culture, and whether they can objectively and critically evaluate western culture; the second is the degree of involvement in learning, that is, whether they are willing to participate in the ideological and political learning activities; and the third is the ability to regulate their negative emotions in the process of learning and practice, such as whether they can overcome the anxiety in language use, confusion and frustration in cultural conflicts, etc. Ideological and political education in College English should guide students to correctly understand foreign countries and cultural differences, strengthen their national identity, and enhance cultural confidence. Teachers should design various interactive tasks and activities to boost students' interest in learning, enhance learning motivation, and increase classroom participation; they should also pay attention to students' emotional changes, offer timely intervention, and provide them with strategies to effectively control negative emotions and help build positive psychology.

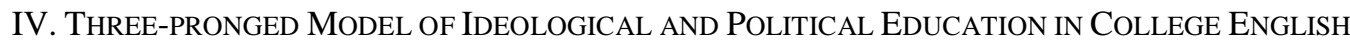

"Opinions on Strengthening and Improving the Ideological and Political Work in Colleges and Universities in the New Situation" puts forward the requirement of adhering to the three-pronged education ("education of all staff, whole process and full coverage"). It is a call for the integration of educational resources and the reconstruction of the longterm educational objectives, standards and system, which lays the keynote and direction for ideological and political education. The ideological and political education in each course must fully conform to the very idea of three-pronged education, and further improve the quality of teaching. Built on the idea of three-pronged education and fourcomponent ideological and political competence, the cultivation model of ideological and political education in College English includes the following three aspects.

\section{A. All Staff, the School, Teachers and Students, Participate and Take Their Own Responsibilities}

"All staff" is a concept put forward in terms of the subjects of education. It means that all the stakeholders, schools, teachers and students, should actively participate in the process of teaching and learning. As the policy maker, the school should not only make clear the overall idea and layout of its ideological and political work, play a role in coordination and organization, but also be able stand at a higher level to guide the direction of various departments and courses, and develop the an evaluation mechanism fit for the school. Also, the school should give priority and provide financial support to teaching and research on ideological and political education. Teachers and students are the main bodies of ideological and political education. Teachers and what they say and do in class have great impact on students. Therefore, teachers should first fully realize the importance and necessity of curriculum ideology and politics, utilize all resources to learn, improve professional skills and ability, and then integrate ideological and political elements into the English class and impart relevant knowledge to students in a planned and strategic way. Meanwhile, they should also take the initiative to monitor students' psychological and mental changes and give timely intervention and thus form a complete cycle of ideological and political teaching through evaluation, feedback and other methods. Students are both the acquirers of knowledge and the creators of meaning. The formation of students' ideology and way of thinking, though affected by the external environment, is ultimately the result of self-selection. Therefore, students should be active and important participants. Without students' involvement, the work is doomed to failure. Students should have a positive attitude, correctly understand the role of English, and participate in learning with an open mind. With the use of English language and skills, students can build healthy personality and positive psychology, to improve and enhance the communication between China and the west, and to spread Chinese culture. 


\section{B. The Whole Process Involves both Internal and External Activities - Learning, Thinking, Doing and Evaluating}

The whole process defines both the phases and continuity of ideological and political education in terms of time. The formation of thought, value, and virtue is the result of internalization. It is the product of input and intake, a process from the input of ideological and political knowledge to the intake of knowledge through active learning and thinking, to the final internalization through application and practice. Therefore, ideological and political education should go through every part of teaching, and effectively connect these parts together to form a complete cycle. In the process of knowledge input, we should pay attention to both the quantity and quality, and the content and method. The content should combine language (English), culture (Chinese and Western Culture) and thought (Chinese traditional morality \& ethics, core socialist values, etc.), and the method should not be limited to one pattern. Task-based and inquiry-based teachings are effective ways to transmit and construct values, and also help to nurture and develop students' creativity, autonomy and efficacy. However, input is not equal to output. Whether the input can be absorbed successfully depends on the effectiveness of processing. In addition to noticing and remembering, the construction and creation of meaning requires higher order thinking. Higher order thinking, analyzing, judging and creating, plays a crucial role in the process of knowledge internalization. Only by critical thinking in a conscious way can learners transform the ideological and political knowledge input into intake and integrate it into their own knowledge system. Output is not only the result of learning, but also the method of learning, which is an important part of the whole process of ideological and political education. Students can extract relevant information from the knowledge learned and produce it through speaking and writing. They can tell Chinese stories in understandable English, spread Chinese culture and conduct cross-cultural communication. Finally, evaluation and feedback are also important means to promote the ideological and political education in College English. The ideological and political knowledge and competence should be incorporated into both the formative and summative evaluations of class learning and the high-stakes tests, such as CET-4 and CET-6. This will definitely have a positive wash-back effect and further promote the development and standardization of the ideological and political education in College English.

\section{The Full-coverage Education Includes First and Second Classrooms and Online \& Offline Learning}

Full coverage defines the scope and field of ideological and political education in terms of space. Curriculum ideology and politics should not only be confined to the classroom, but should be extended to after-class activities and tasks by building a suitable learning environment and to the network platforms by making use of modern educational technologies. First of all, first classroom (classroom teaching) and second classroom (extracurricular activities) should be combined together to create a learning environment. In a broad sense, the second classroom refers to all activities besides classroom teaching, which is an effective extension of the first classroom. With the help of the second classroom, students can broaden their horizon, train their ability and enrich their experience (Peng \& Xie, 2011). College English can fully develop resources for the second classroom on the basis of the first classroom; it can improve students' interest in learning by holding English corners, reading clubs and other activities, and it can also turn to social resources and organize students to participate in volunteer and internship activities, test students' language skills, exercise their practical ability, and raise their ideological level. Secondly, blended learning (online \& offline) should be encouraged and promoted. More efforts should be made to develop online courses with focus on Chinese history and culture, comparison between China and the West, selected readings of Marxist works (English version), critical thinking, etc. These courses can be shared via the Internet and become accessible to more learners. In addition, teachers can use Microblog, Zhihu and other social networking sites to regularly release information about College English ideological and political education, answer questions, resolve confusions and conduct questionnaire surveys. Teachers can also establish class groups on mobile apps such as Wechat, and organize students to carry out cooperative learning by offering materials, initiating discussions, and assigning tasks. Education must catch up with the development of science and technology which has positioned itself as the new direction in today's world (post-epidemic era).

\section{CONCLUSION}

The current change in College English education is a positive response to the needs of China's higher education reform and development in the new era. It is also a new goal after decades of exploration and practice. The ideological and political education in College English course is a multi-agent, multi-stage and multi-level systematic project. It is very important to clarify the inherent nature and the component elements of ideological and political competence in order to set objectives and formulate teaching plans. The goal of College English ideological and political education is to cultivate students' ideological and political competence, and the improvement of competence depends on the growth and maturity of the three-pronged education model. Generally speaking, the ideological and political education in College English curriculum needs to be further explored in both theory and practice. We also need to work hard to promote the reform of College English education and teaching, and further improve the integration of English curriculum and ideological and political education. 


\section{REFERENCES}

[1] Chen Xuezhen. (2019). The Realization of Ideological and Political Education in College English Curriculum from the Perspective of Optimization Theory. China University Education 10: 45-48.

[2] Delphi Project. (1990). Expert Consensus on Critical Thinking. http: //www. insightassessment.com/9dex HTML, retrieved on February 8, 2021.

[3] Du Gangyue \& Sun Ruijuan. (2019). Methodology Research of "Ideological and Political Theories Teaching" in College English Course. Journal of Yan'an University (Social Science Edition) 4: 122-126.

[4] Gao Deyi \& Zong Aidong. (2017). From Ideological and Political Curriculum to Curriculum Ideology and Politics: Constructing Ideological and Political Education Curriculum System from a Strategic Perspective. China Higher Education 1: 43-46.

[5] Gao Yanxia \& Xia Wenyi. (2020). Design and Analysis of Ideological and Political Teaching in College English Course. Computer Age 10: 92-94.

[6] Li Ping, Wang Yuliang, Wu Meiyu, \& Wang Xiaohong. (2018). Feasibility Study on the Implementation of "Integration of Ideological and Political Education in "College English". Journal of Huaihai Institute of Technology (Humanities and Social Sciences Edition) 10: 137-140.

[7] Liu Zhengguang \& Yue Manman. (2020). Resetting the Educational Philosophy and Restructuring Learning Content to Implement Morality Cultivation in Foreign Language Course Instruction. Journal of Foreign languages 5: 21-29.

[8] Peng qiaoyin, Xie Xiangxun. (2011). On the Relationship between the Second Classroom and the First Classroom. The Party Building and Ideological Education in Schools, 5: 45-46.

[9] Qiu Weiguang. (2017). Value Implication and Generation Path of Curriculum Ideological and Political Education. Ideological \& Theoretical Education 7: 10-14.

[10] Song Hui \& Ma Yingxin. (2020). A Case Study on College English Teaching from the Perspective of Curriculum Ideology and Politics. Journal of Dezhou Institute 5: 89-92.

[11] Wu Xinyu. (2020). Teaching Reform and Practice of College English "Curriculum Ideology and Politics" Based on "Production-oriented Approach" -- Taking Huaiyin Normal Institute as an Example. Journal of Higher Education 36: $134-137$.

[12] Xi Jinping. Speech at the National Conference on Ideological and Political Work in Colleges and universities. People's Daily, 2016-12-09.

[13] Xia Wenhong \& He Fang. (2019). The mission of College English "Curriculum Ideology and politics". People's Forum 30: 108-109.

[14] Yang Ying \& Zhuang Enping. (2007). The Construction of Intercultural Communication Competence Framework for Foreign Language Teaching. Foreign Language World 4: 13-21+43.

[15] Zhao Jiwei. (2019). "Curriculum Ideology and Politics": Meaning, Idea, Problems and Countermeasures. Journal of Hubei University of Economics 2: 114-119.

Hui Liu received her Master's degree in foreign language and culture from Nanjing Normal University, China in 2003. She is now an associate professor in the school of English, Beijing International Studies University. Her research interests include English teaching, language policy, and applied linguistics.

Satoshi Tsukamoto received his PHD from Syracuse University, USA in 2000. He is currently a professor in the department of international communication, Aichi University. His research interests are in English education, intercultural communication, and American cultural studies. 